\title{
Simulation and experimental study of novel cascade solar still
}

\author{
Nidal Mouhsin ${ }^{1 *}$, Mariam Bouzaid ${ }^{1}$, Mourad Taha-Janan ${ }^{1}$, and Mohamed Oubrek ${ }^{1}$ \\ ${ }^{1}$ Laboratoire de Mécanique Appliquée et Technologies Centre de Recherche en Sciences et Technologies Industrielles et de la Santé \\ ENSAM, Mohammed V University in RABAT Avenue de l'Armée Royale, BP 6207 Rabat-Instituts, MOROCCO
}

\begin{abstract}
In this paper, a new design of inclined solar still with steppe absorber plate, slope surfaces and baffles were proposed, fabricated, tested and modeled using ANSYS FLUENT software, in order to develop the simple and the cheapest type of desalination. The simulation has been carried out and validated with experimental data for climate conditions of Rabat-Morocco $\left(34^{\circ} 47^{\prime} \mathrm{N}\right)$ obtained from our existing prototype. It has been found that the simulation results are in good agreement with the experimental data. It was also examined that the productivity of the cascade Solar Still was higher from 12:00 to 15:00 hrs. The results indicate that the new design ensures higher productivity.
\end{abstract}

\section{Introduction}

Water is a basic necessity for all living species including humans, animals and plants. it is essential for producing food, turning out power, cooling our planets and keeping up our ecosystem services. The earth surface is covered [1] about $71 \%$ of water which $96.5 \%$ is found in the ocean, $1.4 \%$ in groundwater and $1.7 \%$ as glaciers and ice caps, for the drinkable water on the earth, is only $2.5 \%$.

The growth of population, water pollution, bad water management, and others big problems [2] related to water lead to an increase in consumption and prospection of drinkable water. There are different methods to purifying brackish water, such as electrodialysis, multi-stage flash desalination, multistage heating. Generally, the mentioned processes [3] are used for freshwater production in an industrial scale and not used in a domestic scale due to high cost and high energy consumption.

the world has high solar potential and an abundance of undesirable groundwater resources [4]. Therefore, in these regions, the direct solar desalination can be an appropriate way to produce fresh water in a domestic scale. Solar desalination is one of the economical applicable techniques to purify brackish water because it's offering a simple construction and fabrication. The main advantage of using solar stills it is clean and has no adverse effect on the environment, however, in comparison with other methods the productivity is very low.

Therefore, many researchers executed different techniques to enhance the productivity of this type of desalination. It observed that the depth of saline water in the absorber plate has a big effect on the yield of solar still. The freshwater production efficiency of stepped cascade solar still is more than the basin solar still [5].

The proposed techniques to enhance the productivity of this type of desalination, According to Kabeel et al. [6], productivity reaches almost $57.3 \%$ while using a number of trays with different widths and depths. R. Sammul Hansen et al [7] used various wick materials on different absorber plats; the production rate was increased by $48.9 \%$ to $72.2 \%$. Mohammed and Tabrizi [8] increased productivity by $32 \%$, by the integration of PCM in cascade solar still. Awad and Agzouz [9] used stepped solar still with humidification and dehumidification, increasing productivity by about $57 \%$ and the efficiency by $47 \%$. Yadav et al. [10] used a Stepped and weir type solar still increases the distillate output around 60-80\%.Zoori et al. [11] used energy and exergy in weir type cascade solar still, the efficiency of energy and exergy increases by $83.3 \%$ and $10.5 \%$ respectively.

As a contribution of seeking an improvement of the productivity of a solar still, our work presents a 3D CFD model of novel cascade solar still design developed with ANSYS Workbench then simulated by fluent in order to validate the proposed design. A comparison was made with experimental results and simulation ones of cascade solar still.

\section{Structure of Solar Still}

The new device was developed by Bouzaid et al. [12] and has an inclined glass cover with an angle of $30^{\circ}$, the absorber plate is formed with a number of steps. Baffles were joined to horizontal and inclined surfaces of $35^{\circ}$ 
and weirs to minimize the velocity of saline water. See Figure 2.

The details of different elements and parts of this device are explained by Bouzaid et al. [14] and presented in figure1.

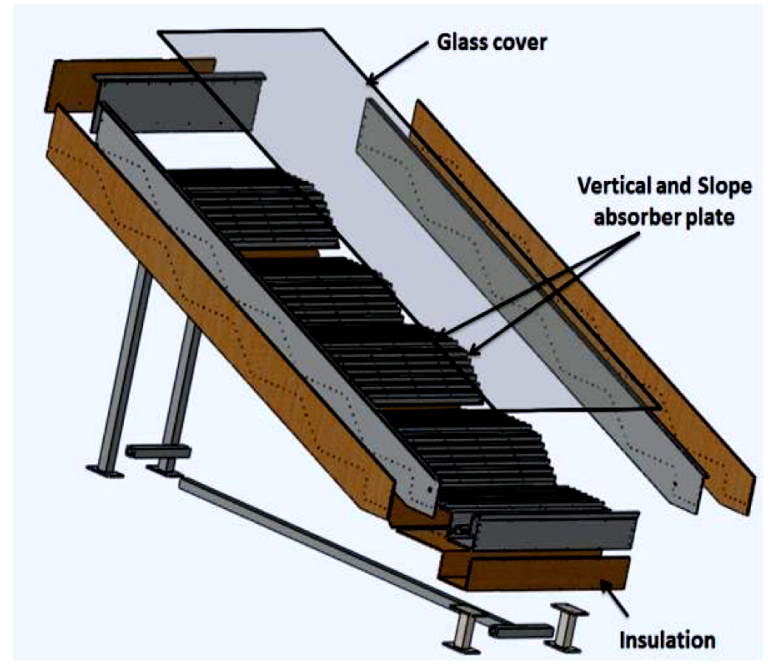

Fig.1. Elements and parts of new design for cascade solar still.

The glass cover functions are:

- Transmit the radiation.

- Blocked the radiation to be-transmitted by the inner face of the basin.

- Condensing surface of the steam.

The glass is inclined over than $25^{\circ}$ for better orientation relative to the sun and to facilitate the runoff of condensate water to the collector.

The main advantages of the new construction of the absorber plate are:

- Better absorption of solar radiation.

- Minimum depth of water.

- Quick water heating.

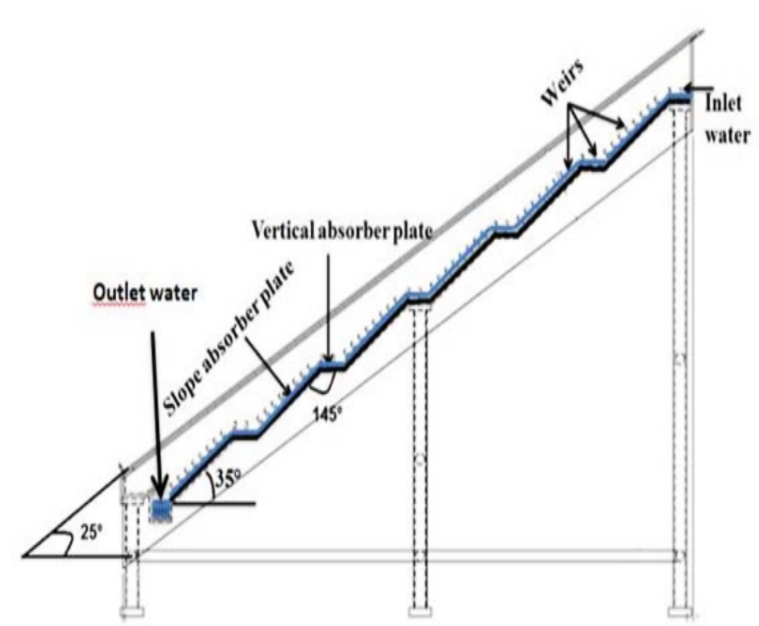

Fig .2. The simplified design of the stepped absorber plate.

\section{Design Modeling With ANSYS}

The 3D geometry of solar still was modeled using ANSYS Design Modeler with all the geometrical constraints same as in the experimental setup.

It's the gate to the geometry manipulation for analysis with software from ANSYS and it necessitates special care for defining surfaces and boundaries.

\subsection{ANSYS Meshing:}

The most critical part of the simulation is mesh generation. Too many cells may result in long solver runs, and too few may lead to inaccurate results. Meshing technology of ANSYS provides balancing requirements and get the correct mesh for every simulation with the most automatic possible way. The most powerful parts of these tools are transported in a single environment to obtain a powerful meshing.

\subsection{ANSYS solution processor:}

The solution obtained by using this process for the finite element model generated in the preprocessor, the important tasks in this processor are:

- Define analysis type and analysis options.

- Specify boundary conditions.

- Obtain a solution.

- The numerical studies were based on the following assumptions:

- Thermo-physical properties of aluminum, glass, and air remain constant during the process.

- Thermal contact between the glass and the walls of cascade solar still and their environment is perfect.

- Cascade solar still wall temperature is considered equal and undisturbed.

\subsection{Boundary conditions}

The boundary conditions are specified to solve the continuity and momentum equations. The running simulation was about 10 hours, due to a high number of time steps and computer time constraints. the received solar radiation by the basin, the ambient temperature, the water and glass temperatures based on the solar calculator in fair weather conditions. The solar intensity was based on the absorption factor and the emissivity of the glass, the bottom, and the water. The heat transfer coefficient of the side walls was calculated and maintained constant for the overall process. 


\section{EXPERIMENTAL PROCEDURE}

The experiment was realized from 8 am to $6 \mathrm{pm}$; for each 1 - hour time interval an average temperature was set as the boundary condition.

The cascade solar still is fed with 25 liters of saltwater linked to a saline storage tank. Six thermocouples are installed at the inner face of the absorber plate and 3 on the external face of the glass cover. Three measurements were carried on the absorber, the top, middle and bottom. The solar intensity and the ambient temperature are collected during the experimental process which is realized at the Higher Normal School of Technical Education in RabatMorocco $\left(34^{\circ} 47^{\prime} \mathrm{N}\right)$.

\section{SIMULATION RESULTS}

The results obtained from the simulation analysis and experimental study of a cascade solar still presented in this section.

The main objective of the study, was to develop a CFD model of a Simple Solar Still to validate the results with experimental. A multi-phase model has been developed in ANSYS which accounts for all the three phases present in the solar still, (air, liquid water, and water vapor). The simulation results have been linked with the experimental data.

Figure 3 shows the temperature experimental and simulated of the basin, as can be seen; the simulation outcomes have been compared with the experimental data. The readings don't exactly match, but they follow similar patterns. The likely reason for this variation is that the intensity of solar radiation in the simulation doesn't account for natural attenuation.

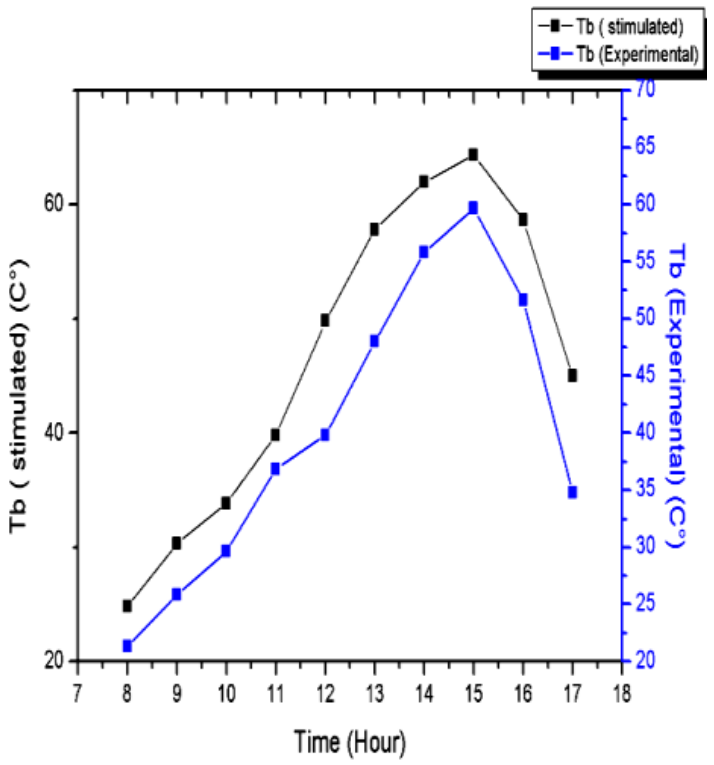

Fig.3. The absorber plate temperature Simulated and Experimental Results.

In the figure 4, the simulation results of solar intensity have been compared with the experimental data, the results compare are well perfectly match and it

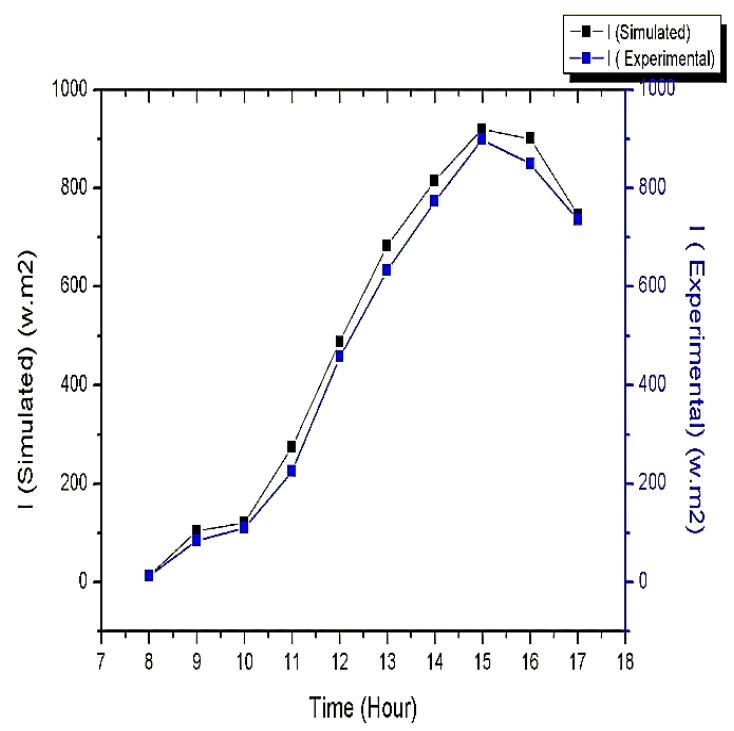

follows a similar pattern.

Fig.4. Solar intensity variation of simulated and experimental data.

Figure .5 shows the variation of the absorber temperature has a similar variation to the solar intensity. The absorber plate temperature and the solar intensity have achieved the maximum at mid-noon. The solar radiation increases, and it increases the absorber

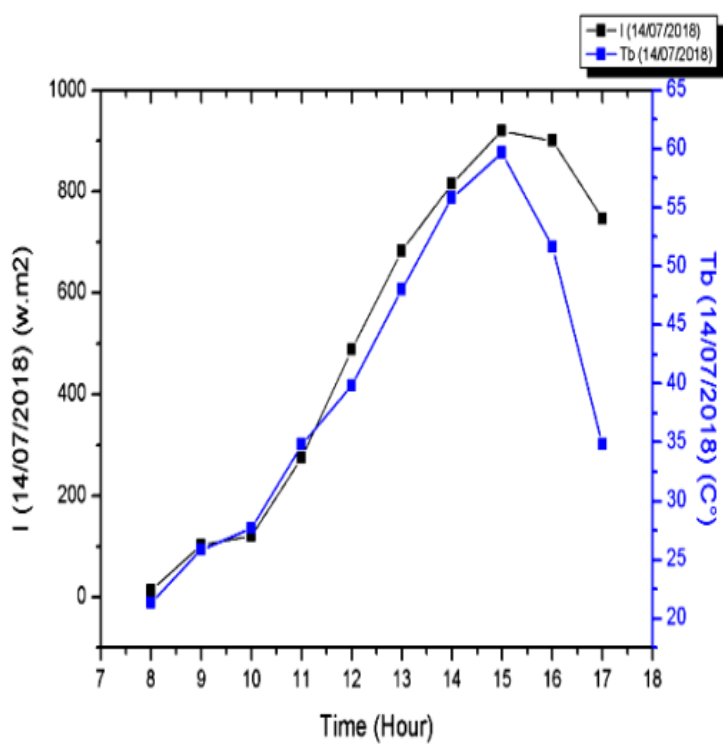

temperature, for a maximum more than $60{ }^{\circ} \mathrm{C}$ and 900 $\mathrm{w} . \mathrm{m}^{2}$ of solar intensity.

Fig.5. Hourly variations of the absorber plate temperature measured on the 14th of July2018.

The water productivity as shows in figure 6 has achieved a maximum of $1.66 \mathrm{~kg} / \mathrm{m} 2 \mathrm{hr}$, after mid-noon, when the intensity of solar radiation increases, more distilled water is produced due to a higher temperature. After reaching its maximum, the productivity decreases as the intensity of Solar radiation drops. 


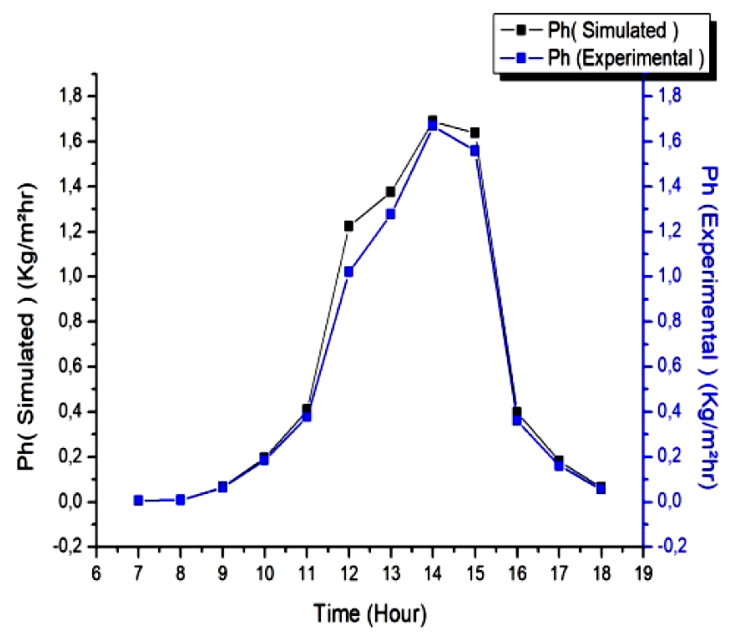

Fig.6. Hourly Productivity of the solar still (simulated/experimental).

An experimental analysis was done, the results show that the absorber plate temperature and productivity can reach more than $60{ }^{\circ} \mathrm{C}$ and $1.6 \mathrm{~kg} / \mathrm{m} 2 \mathrm{hr}$ respectively. Important values proved the productivity of the new design, in comparison with the experimental results of the single basin presented by O.O. Badran [15], the absorber plate temperature and productivity reach more than $50^{\circ}$ and $0.6 \mathrm{~kg} / \mathrm{m} 2 \mathrm{hr}$ respectively. That proves the effect of water depth on the productivity of the still basin.

\section{Conclusion}

This paper presents a new design of solar still with stepped absorber plate, sloped surfaces, for minimizing the depth of saline water due to enhance the productivity of this cheapest type of desalination.

A comparison is made between simulation results and experimental data of the absorber plate. The simulation model has been tested to validate the quality and capability of the experimental model.

Simulated results show that computational fluid dynamics is a powerful tool for design parametric for cascade solar still. For the future work can be done by integrated more baffles to the absorber plate in consideration of other different design parameters.

\section{References}

[1] UNESCO (2003). Political inertia exacerbates water crisis, says World Water Development Report First UN system-wide evaluation of global water resources, 05-03.

[2] LIU Chang-ming, WANG Hong-rui. An analysis of the relationship between water resources and population-economysociety-environment
Journal of Natural Resources, 2003, 18 (5):635644.

[3] Rajat Bharadwaj, Deepika Singh and Alpana Mahapatra, Seawater desalination technologies. Int. J. Nuclear Desalination, Vol. 3, No. 2, 2008

[4] Tabrizi FF, Dashtban M, Moghaddam H, Razzaghi $\mathrm{K}$. Effect of water flow rate on internal heat and mass transfer and daily productivity of a weir-type cascade solar still. Desalination. 2010; 260:239-47.

[5] Sadineni SB, Hurt R, Halford CK, Boehm RF. Theory and experimental investigation of a weirtype inclined solar still. Energy. 2008; 33:71-80.

[6] K.V. Reddy, N.Ghaffour, Overview of the cost of desalinated water and costing methodologies- K.V . Reddy, N. Ghaffour- Desalination 205 (2007) 340353-Elsevier

[7] Kabeel, Khalil, Omara and Younes. "Theoretical and experimental parametric study of modified stepped solar still." Desalination 289 (2012): 1220.

[8] R. Sammul Hansen, C. Surya Narayanan, K. Kalidasa Murgavel. "Performance analysis on inclined solar still with different new wick materials and wire mesh." Desalination 358 (2015): 1-8

[9] Dashtban M, Tabrizi FF. Thermal analysis of a weir-type cascade solar still integrated with PCM storage. Desalination. 2011; 279 (1):415-422.

[10] Awad MM, El-Agouz SA. Enhancement of the performance of stepped solar still using humidification-dehumidification processes. Nature and Science. 2013; 11(2):88-98.

[11] Kumar M, Yadav C, Manchanda H. Thermal performance of a weir-type cascade solar still: An experimental study. International Journal of Advance Research and Innovation. 2016; 4(1):339_ 344.

[12] Zoori HA, Tabrizi FF, Sarhaddi F, Heshmatnezhad F. Comparison between energy and exergy efficiencies in a weir type cascade solar still. Desalination. 2013; 325:113-121.

[13] M. Bouzaid, O. Ansari1, M. Taha-Janan1 and M. Oubrek Experimental and Theoretical Analysis of a Novel Cascade Solar Desalination Still. Tech Science Press FDMP, vol.14, no.3, pp.177200,2018.

[14] M. Bouzaid, M. Oubrek, O. Ansari, A. Sabri and M. Taha Janan. Mathematical Analysis of a New Design for Cascade Solar Still. FDMP, vol.12, no.1, pp.15-32, 2016.

[15] O.O.Badran Experimental study of the enhancement parameters on a single slope solar still 
productivity. Volume 209, Issues 1-3, 30 April 2007, Pages 136-143 